\title{
Serum Contactin-1 in CIDP
}

\section{A Cross-Sectional Study}

Luuk Wieske, MD, PhD, Lorena Martín-Aguilar, MD, Janev Fehmi, MD, Cinta Lleixà, MD, Marleen J.A. Koel-Simmelink, PhD, Madhurima Chatterjee, PhD, Zoë van Lierop, MD, Joep Killestein, MD, PhD, Camiel Verhamme, MD, PhD, Luis Querol, MD, PhD, Simon Rinaldi, MD, PhD, Charlotte E. Teunissen, PhD,* and Filip Eftimov, MD, PhD*

Neurol Neuroimmunol Neuroinflamm 2021;8:e1040. doi:10.1212/NXI.0000000000001040

\section{Abstract}

\section{Objective}

To investigate whether serum levels of contactin-1, a paranodal protein, correlate with paranodal injury as seen in patients with CIDP with antibodies targeting the paranodal region.

\section{Methods}

Serum contactin-1 levels were measured in 187 patients with CIDP and 222 healthy controls. Paranodal antibodies were investigated in all patients.

\section{Results}

Serum contactin-1 levels were lower in patients $(\mathrm{N}=41)$ with paranodal antibodies compared with patients $(\mathrm{N}=146)$ without paranodal antibodies $(p<0.01)$ and showed good discrimination between these groups (area under the curve 0.84; 95\% CI: 0.76-0.93).

\section{Conclusions}

These findings suggest that serum contactin-1 levels have the potential to serve as a possible diagnostic biomarker of paranodal injury in CIDP.

\section{Classification of Evidence}

This study provides class II evidence that serum contactin-1 levels can discriminate between patients with CIDP with or without paranodal antibodies with a sensitivity of $71 \%$ (95\% CI: $56 \%-85 \%)$ and a specificity of $97 \%$ (95\% CI: $83 \%-100 \%)$.

\author{
Correspondence \\ Dr. Wieske \\ I.wieske@amsterdamumc.nl
}

\section{MORE ONLINE}

\section{Class of Evidence}

Criteria for rating

therapeutic and diagnostic

studies

NPub.org/coe

\footnotetext{
*These authors contributed equally to this work.
}

From the Department of Neurology and Neurophysiology (L.W., C.V., F.E.), Amsterdam Neuroscience, Amsterdam UMC, Location AMC, Amsterdam, the Netherlands; Neuromuscular Diseases Unit (L.M.-A., C.L., L.Q.), Department of Neurology, Hospital de La Santa Creu i Sant Pau, Universitat Autònoma de Barcelona, Spain; Department of Clinical Neurosciences (J.F., S.R.), West Wing, John Radcliffe Hospital, Oxford, United Kingdom; Neurochemistry Lab (M.J.A.K.-S., C.E.T.), Department of Clinical Chemistry, Amsterdam Neuroscience, Amsterdam UMC, Vrije Universiteit, Amsterdam, the Netherlands; and Department of Neurology (M.C., Z.L., J.K.), Amsterdam Neuroscience, Amsterdam UMC, Location VU Medical Center, Amsterdam, the Netherlands.

Go to Neurology.org/NN for full disclosures. Funding information is provided at the end of the article. 


\section{Glossary}

AUC = area under the curve; CNTN1 = contactin $-1 ;$ IVIg $=$ IV immunoglobulin; ROC $=$ receiver operating characteristic; sCNTN1 = serum levels of contactin-1.

Most patients with CIDP show a good response to first-line treatments like corticosteroids or IV immunoglobulin (IVIg). However, several reports have emphasized that patients with CIDP and paranodal antibodies have poor response to first-line treatments. Early identification of these patients is important to guide treatment decisions and prevent long-term axonal damage.

Contactin-1 (CNTN1) is an axonal protein that anchors paranodal myelin in complex with contactin-associated protein 1 (Caspr1) and neurofascin-155 (NF-155). ${ }^{1}$ Pathogenic IgG4 antibodies targeting these paranodal proteins are found in up to $10 \%{ }^{2}$ The CNTN1 (protein) exists in a soluble form making it good biomarker candidate for paranodal damage. ${ }^{3}$ Decreased CNTN1 levels have been found in other demyelinating disorders such as MS and neuromyelitis optica. ${ }^{4,5}$ We hypothesize that paranodal injury in CIDP leads to altered serum levels of contactin-1 (sCNTN1) in patients with CIDP with paranodal antibodies compared to CIDP patients without.

\section{Methods}

Patients were selected from cohorts from 3 CIDP tertiary referral centers in the Netherlands (Amsterdam), Spain (Barcelona), and the United Kingdom (Oxford). The Amsterdam cohort comprised patients who were included in ongoing prospective CIDP cohort studies $(\mathrm{N}=103)$. The Barcelona ( $\mathrm{N}$ $=55)$ and Oxford $(\mathrm{N}=30)$ cohorts comprised nonconsecutive patients who were referred because of suspected antibodymediated CIDP. All patients fulfilled the definite or probable EFNS/PNS criteria. ${ }^{6}$ Samples were collected during different disease stages. In addition, 222 healthy controls were included.

\section{Standard Protocol Approvals, Registrations, and Patient Consents}

The study was approved by the local medical ethical committees of participating centers. All patients provided signed informed consent.

\section{Serum Measurements of CNTN1 and Antibodies}

Isolated serum was stored at $-80^{\circ} \mathrm{C}$ in each center. sCNTN1 levels were measured centrally in the Neurochemistry Laboratory at Amsterdam UMC on Bio-Plex 200 system (Bio-Rad Laboratories, Veenendaal, The Netherlands) using the Human Magnetic Luminex Assay (LXSAHM; R\&D Systems, Minneapolis, MN) according to the manufacturer's instructions. Samples were randomized and analyzed in duplicate in a 6-fold dilution, blinded for the presence of paranodal antibodies. Assay validation is described elsewhere. ${ }^{4}$ The intraassay $\mathrm{CV}$ was $3.2 \%$, and measurements with an intra-assay $\mathrm{CV}$
$>15 \%$ and outliers were repeated and were excluded if the CV remained $>15 \%(\mathrm{~N}=1)$. For $\mathrm{sCNTN} 1$ measurements below the LLOQ a value was assigned of half of the manufacturer's reported LLOQ (i.e., $1.8 \mathrm{pg} / \mathrm{mL}$ ).

The presence of paranodal antibodies was determined at the time of sampling in Barcelona (for the Amsterdam and Barcelona cohort) and Oxford (for the Oxford cohort) using dedicated cell-based assays and ELISAs against NF-155, NF186, CNTN1, and Caspr1.

\section{Statistical Analysis}

A receiver operating characteristic (ROC) curve with area under the curve (AUC) was used to investigate the discriminatory potential of $\mathrm{sCNTN} 1$ for the presence or absence of paranodal antibodies. The Youden index was used to select the optimal cutoff point for the ROC curve. Data were analyzed using $\mathrm{R}$, version 3.6.2.

\section{Data Availability}

The data that support the findings of this study are available from the corresponding author on reasonable request.

\section{Results}

A total of 188 patients with CIDP and 222 healthy controls were included. One measurement in a patient with CIDP was excluded due to high CV. Clinical data for patients with CIDP can be found in the table. Paranodal antibodies were found in $41(22 \%)$ patients, NF-155 antibodies in 18 patients, CNTN1 antibodies in 13, Caspr1 antibodies in 6, and NF-140 antibodies in 4 . Treatment status at sampling is shown in the table.

\section{sCNTN1 in Healthy Controls}

In 222 healthy controls (mean age 46 years; SD 14; range $19-98$ years), median sCNTN1 levels were $12,470 \mathrm{pg} / \mathrm{mL}$ (IQR 10,160-14,440 pg/mL). sCNTN1 levels were not associated with age ( $\mathrm{r}$ : $-0.0795 \% \mathrm{CI}:-0.20$ to 0.06 ).

\section{sCNTN1 in Patients With and Without Paranodal Antibodies}

The figure shows sCNTN1 levels for patients with or without paranodal antibodies. Median sCNTN1 levels were lower in patients with paranodal antibodies compared with patients without antibodies $(p<0.01)$ and lowest in patients with CNTN1 antibodies. All 6 samples that were below the LLOQ were present in this subgroup (figure). Compared with healthy controls, median sCNTN1 levels were lower in patients with CIDP, both in patients without (p:0.04) and in patients with paranodal antibodies $(p<0.01)$. There was no correlation 
Table Clinical Data of Patients With CIDP

\begin{tabular}{|c|c|c|}
\hline & $\begin{array}{l}\text { Patients } \\
\text { without } \\
\text { paranodal } \\
\text { antibodies } \\
(N=146)\end{array}$ & $\begin{array}{l}\text { Patients with } \\
\text { paranodal } \\
\text { antibodies } \\
(\mathbf{N}=\mathbf{4 1})\end{array}$ \\
\hline Age $(y)$, mean $( \pm S D)^{a}$ & $60( \pm 15)$ & $55( \pm 16)$ \\
\hline Male, $\mathbf{n}(\%)^{\mathbf{b}}$ & $101(69 \%)$ & $32(80 \%)$ \\
\hline \multicolumn{3}{|l|}{ Clinical phenotype $^{c}$} \\
\hline Classic, n (\%) & $121(84 \%)$ & $26(74 \%)$ \\
\hline Acute onset classic, $n$ (\%) & $14(10 \%)$ & $10(29 \%)$ \\
\hline Asymmetric, n (\%) & $15(10 \%)$ & 0 \\
\hline Sensory predominant, n (\%) & $3(2 \%)$ & $3(9 \%)$ \\
\hline Motor predominant, n (\%) & $4(3 \%)$ & $2(6 \%)$ \\
\hline Distal predominant, n (\%) & $2(1 \%)$ & $4(11 \%)$ \\
\hline \multicolumn{3}{|l|}{ Presence of paranodal antibodies } \\
\hline NF-155 +, n (\%) & & $18(44 \%)$ \\
\hline CNTN1 +, n (\%) & & $13(32 \%)$ \\
\hline Caspr1 +, n (\%) & & $6(14 \%)$ \\
\hline NF-186 +, n (\%) & & $4(10 \%)$ \\
\hline
\end{tabular}

Treatment status at moment

of sampling ${ }^{d}$

\begin{tabular}{lll}
\hline Untreated & $53(37 \%)$ & $5(13 \%)$ \\
\hline Receiving treatment & $92(63 \%)$ & $33(87 \%)$ \\
\hline
\end{tabular}

Abbreviations: CNTN1 $=$ contactin-1; Caspr $1=$ contactin 1 associated protein 1: NF-155 = neurofascin-155; NF-186 = neurofascin-186.

${ }^{\text {a }}$ Missing for 6 patients.

${ }^{\mathrm{b}}$ Missing for 1 patient.

${ }^{\mathrm{C}}$ Missing for 7 patients.

${ }^{\mathrm{d}}$ Missing for 4 patients.

between sCNTN1 levels and antibody titers at the time of measurement, including in those patients with CNTN1 antibodies (data not shown). For discriminating between the presence and absence of paranodal antibodies, the AUC of the ROC curve was 0.84 (95\% CI: 0.76-0.93). The associated optimal cutoff value was $5,810 \mathrm{pg} / \mathrm{mL}$, indicating that lower values had a sensitivity $71 \%$ (95\% CI: $56 \%-85 \%$ ) and a specificity of $97 \%$ (95\% CI: $83 \%-100 \%)$ to discriminate between CIDP with or without paranodal antibodies.

\section{Classification of Evidence}

This study provides class II evidence that serum contactin-1 levels can discriminate between patients with CIDP with or without paranodal antibodies with a sensitivity of $71 \%$ (95\% CI: $56 \%-85 \%)$ and a specificity of $97 \%$ (95\% CI: $83 \%-100 \%$ ).

\section{Discussion}

We found that sCNTN1 levels were distinctly lower in patients with CIDP with paranodal antibodies and were highly specific for the presence of paranodal antibodies in patients with CIDP. Serum measurements of CNTN1 may therefore aid in diagnosing paranodal CIDP mediated by IgG4 antibodies. Testing for CIDP antibodies is not yet widely available, which can delay diagnosis, whereas sCNTN1 level testing is simple, cheap, and

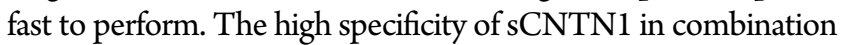
with the low overall prevalence of paranodal antibodies (estimated at $10 \%$ ) indicates that normal sCNTN1 values may have a high negative predictive value and may therefore by used as a screening assay preceding focused assays testing for the presence of specific paranodal antibodies in patients with CIDP with a clinical picture suggesting the presence of paranodal antibodies. Also, low or undetectable sCNTN1 may guide early treatment choices as traditional first-line treatments are frequently ineffective in paranodal CIDP mediated by IgG4 antibodies. ${ }^{8}$

Other studies in demyelinating disorders of the CNS also found decreased sCNTN1 levels in serum, although not as low as seen in patients with CIDP with paranodal antibodies. ${ }^{4,5}$ Although we found a significant difference on group level between patients with CIDP without paranodal antibodies and healthy controls, the difference was small with considerable overlap in sCNTN1 levels between patients with CIDP without paranodal antibodies and healthy controls. It is therefore unlikely that sCNTN1 can be used to confirm the diagnosis of CIDP in general. Longitudinal studies during various disease stages are needed to further study the potential role of sCNTN1 as biomarker of disease activity in patients with CIDP with and without paranodal antibodies.

In this study, there was uneven recruitment of patients across different states of disease activity reflected that could partly contribute to the results. The lack of patients with acute neuropathies such as the Guillain-Barre syndrome can also be seen as limitation of this study. Also, in the subgroup of patients with paranodal antibodies, there is a risk of selection bias due to nonconsecutive recruitment in some of the cohorts. We cannot rule out interference with our assay by CNTN1 antibodies binding to the antigen at the same epitope as the assay antibodies as an explanation for the low and unmeasurable sCNTN1 levels seen in this subgroup. We presume that assay interference is not a major factor influencing our results because sCNTN1 levels were also distinctly reduced in patients with other paranodal antibodies and because we did not find a correlation between sCNTN1 and antibody titers.

\section{Conclusion}

These findings indicate that serum contactin-1 level is a promising new diagnostic biomarker of paranodal injury in CIDP.

\section{Study Funding}

This study was supported by an Amsterdam UMC Neuroscience Alliance grant. The sponsor was not involved in design, analysis, interpretation, or writing of the manuscript. 


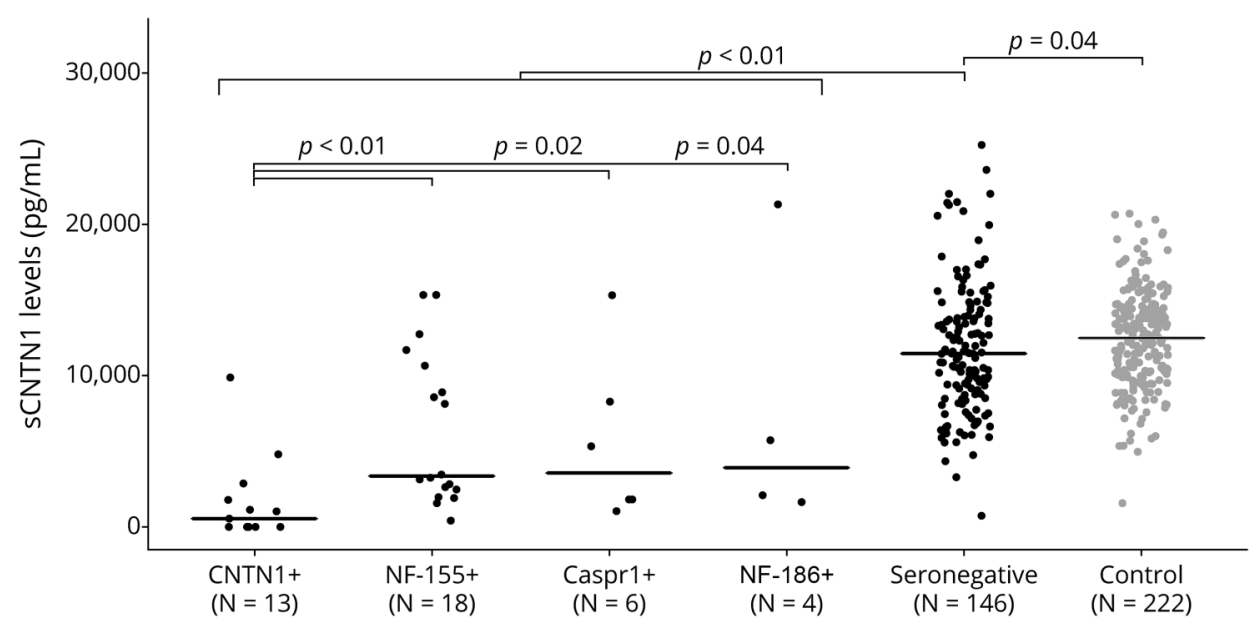

Serum contactin-1 (sCNTN1) levels in healthy controls (gray) and patients with CIDP (black) categorized according to the presence or absence of the different nodal and paranodal antibodies. The black line indicates the median per group. CNTN1 = contactin-1; Caspr1 = contactin-1-associated protein 1; NF$155=$ neurofascin-155; NF186 = neurofascin 186.

\section{Disclosure}

L. Wieske received research grants from Grifols and the GBS/ CIDP Foundation for the study of disease activity biomarkers in CIDP. L. Martín-Aguilar has received speaking honoraria from Roche. J. Fehmi is funded by the GBS/CIDP Foundation International Benson Fellowship (Grant 1709HM001/ SB17) and previously received funding from the Guarantors of Brain entry fellowship award. C. Lleixà, M.J.A. KoelSimmelink, M. Chatterjee, and Z. van Lierop report no disclosures relevant to the manuscript. J. Killestein has conducted contracted MS research for F. Hoffmann-La Roche Ltd, Biogen, Teva, Merck, Novartis, and Sanofi/Genzyme. C. Verhamme is a member of a clinical advisory board (CAB) of Inflectis France; payment was done to his organization for attending a $\mathrm{CAB}$ meeting, outside the submitted work. L. Querol supported by Fondo de Investigaciones Sanitarias (FIS), Instituto de Salud Carlos III, Spain, and FEDER under grant FIS19/01407 has provided expert testimony for Grifols, Sanofi-Genzyme, Novartis, UCB, Roche, and CSL Behring and received research funds from Novartis Spain, SanofiGenzyme, and Grifols. S. Rinaldi has received speaker's honoraria from Fresenius, Alnylam and Excemed and payments to provide expert medicolegal advice on inflammatory neuropathies and their treatment. He has received complimentary registration and prize money from the Peripheral Nerve Society and a travel bursary from the European School of Neuroimmunology. He has received research funding from the Pathological Society of Great Britain and Ireland, the Wellcome Trust, the Academy of Medical Sciences, the Medical Research Council (United Kingdom), the University of Oxford (John Fell Fund, COVID-19 Internal Research Fund), and the British Medical Association. He is a member of the GBS and Associated Inflammatory Neuropathies (GAIN) patient charity medical advisory board. He runs a not-forprofit nodal/paranodal antibody testing service at the Nuffield Department of Clinical Neurosciences, John Radcliffe Hospital, Oxford, United Kingdom, in partnership with Clinical
Laboratory Immunology of Oxford University Hospitals. He is UK Chief Investigator for the ADHERE trial and has received consultancy payments from Argenx for the preparation and delivery of presentations regrading this trial. C.E. Teunissen's research is supported by the European Commission (Marie Curie International Training Network, JPND), Health Holland, the Dutch Research Council (ZonMW), Alzheimer Drug Discovery Foundation, The Selfridges Group Foundation, Alzheimer Netherlands, and Alzheimer Association. She has a collaboration contract with $\mathrm{ADx}$ Neurosciences and Quanterix, performed contract research, or received grants from Axon Neuroscience, Brainstorm Therapeutics, Celgene, EIP Pharma, iEsai, Roche, and Toyama. F. Eftimov reports grants from ZonMw (Dutch Governmental Agency) and Prinses Beatrix Spierfonds (Dutch Charity Organization) and grants from CSL Behring, Kedrion, Terumo BCT, and Takeda Pharmaceutical Company, outside the submitted work. Grants were paid to institution and are used for investigator-initiated randomized controlled trials and studies within INCbase, an international CIDP registry. In addition, he received consultancy fee from UCB Pharma, paid to institution, outside the submitted work. Go to Neurology.org/NN for full disclosures.

\section{Publication History}

Received by Neurology: Neuroimmunology \& Neuroinflammation December 17, 2020. Accepted in final form May 20, 2021.

Appendix Authors

\begin{tabular}{|c|c|c|}
\hline Name & Location & Contribution \\
\hline $\begin{array}{l}\text { Luuk Wieske, } \\
\text { MD, PhD }\end{array}$ & $\begin{array}{l}\text { Amsterdam UMC, location } \\
\text { AMC, Amsterdam, the } \\
\text { Netherlands }\end{array}$ & $\begin{array}{l}\text { Designed and } \\
\text { conceptualized the study; } \\
\text { major role in the } \\
\text { acquisition of data; } \\
\text { analyzed the data; and } \\
\text { drafted the manuscript for } \\
\text { intellectual content }\end{array}$ \\
\hline
\end{tabular}


Appendix (continued)

\begin{tabular}{|c|c|c|}
\hline Name & Location & Contribution \\
\hline $\begin{array}{l}\text { Lorena } \\
\text { Martín- } \\
\text { Aguilar, MD }\end{array}$ & $\begin{array}{l}\text { Hospital de la Santa Creu i } \\
\text { Sant Pau, Universitat } \\
\text { Autònoma de Barcelona, } \\
\text { Spain }\end{array}$ & $\begin{array}{l}\text { Major role in the } \\
\text { acquisition of data; } \\
\text { interpreted the data; and } \\
\text { revised the manuscript for } \\
\text { intellectual content }\end{array}$ \\
\hline $\begin{array}{l}\text { Janev Fehmi, } \\
\text { MD }\end{array}$ & $\begin{array}{l}\text { John Radcliffe Hospital, } \\
\text { Oxford, United Kingdom }\end{array}$ & $\begin{array}{l}\text { Major role in the } \\
\text { acquisition of data; } \\
\text { interpreted the data; and } \\
\text { revised the manuscript for } \\
\text { intellectual content }\end{array}$ \\
\hline $\begin{array}{l}\text { Cinta Lleixà, } \\
\text { MD }\end{array}$ & $\begin{array}{l}\text { Hospital de la Santa Creu i } \\
\text { Sant Pau, Universitat } \\
\text { Autònoma de Barcelona, } \\
\text { Spain }\end{array}$ & $\begin{array}{l}\text { Major role in the } \\
\text { acquisition of data; } \\
\text { interpreted the data; and } \\
\text { revised the manuscript for } \\
\text { intellectual content }\end{array}$ \\
\hline $\begin{array}{l}\text { Marleen J.A. } \\
\text { Koel- } \\
\text { Simmelink, } \\
\text { PhD }\end{array}$ & $\begin{array}{l}\text { Amsterdam UMC, location } \\
\text { Vrije Universiteit, Amsterdam, } \\
\text { the Netherlands }\end{array}$ & $\begin{array}{l}\text { Major role in the } \\
\text { acquisition of data; } \\
\text { interpreted the data; and } \\
\text { revised the manuscript for } \\
\text { intellectual content }\end{array}$ \\
\hline $\begin{array}{l}\text { Madhurima } \\
\text { Chatterjee, } \\
\text { PhD }\end{array}$ & $\begin{array}{l}\text { Amsterdam UMC, location } \\
\text { Vrije Universiteit, Amsterdam, } \\
\text { the Netherlands }\end{array}$ & $\begin{array}{l}\text { Major role in the } \\
\text { acquisition of data; } \\
\text { interpreted the data; and } \\
\text { revised the manuscript for } \\
\text { intellectual content }\end{array}$ \\
\hline $\begin{array}{l}\text { Zoë van } \\
\text { Lierop, MD }\end{array}$ & $\begin{array}{l}\text { Amsterdam UMC, location } \\
\text { Vrije Universiteit, Amsterdam, } \\
\text { the Netherlands }\end{array}$ & $\begin{array}{l}\text { Interpreted the data and } \\
\text { revised the manuscript for } \\
\text { intellectual content }\end{array}$ \\
\hline $\begin{array}{l}\text { Joep } \\
\text { Killestein, } \\
\text { MD, PhD }\end{array}$ & $\begin{array}{l}\text { Amsterdam UMC, location } \\
\text { Vrije Universiteit, Amsterdam, } \\
\text { the Netherlands }\end{array}$ & $\begin{array}{l}\text { Designed and } \\
\text { conceptualized the study } \\
\text { and revised the } \\
\text { manuscript for intellectual } \\
\text { content }\end{array}$ \\
\hline $\begin{array}{l}\text { Camiel } \\
\text { Verhamme, } \\
\text { MD, PhD }\end{array}$ & $\begin{array}{l}\text { Amsterdam UMC, location } \\
\text { AMC, Amsterdam, the } \\
\text { Netherlands }\end{array}$ & $\begin{array}{l}\text { Interpreted the data and } \\
\text { revised the manuscript for } \\
\text { intellectual content }\end{array}$ \\
\hline
\end{tabular}

Appendix (continued)

\begin{tabular}{lll}
\hline Name & Location & Contribution \\
\hline $\begin{array}{lll}\text { Luis Querol, } \\
\text { MD, PhD }\end{array}$ & $\begin{array}{l}\text { Hospital de la Santa Creu i Sant } \\
\text { Pau, Universitat Autonoma de } \\
\text { Barcelona, Spain }\end{array}$ & $\begin{array}{l}\text { Interpreted the data and } \\
\text { revised the manuscript for } \\
\text { intellectual content }\end{array}$
\end{tabular}

Simon John Radcliffe Hospital, Interpreted the data and

Rinaldi, MD, Oxford, United Kingdom revised the manuscript for

PhD intellectual content

Charlotte E. Amsterdam UMC, location Designed and

Teunissen, Vrije Universiteit, Amsterdam, conceptualized the study;

PhD the Netherlands analyzed the data; and drafted the manuscript for intellectual content

Filip Eftimov, Amsterdam UMC, location Designed and

MD, PhD AMC, Amsterdam, the Netherlands conceptualized the study analyzed the data; and drafted the manuscript for intellectual content

\section{References}

1. Faivre-Sarrailh C, Devaux JJ. Neuro-glial interactions at the nodes of Ranvier: implication in health and diseases. Front Cell Neurosci. 2013;7:196.

2. Bunschoten C, Jacobs BC, Van den Bergh PYK, Cornblath DR, van Doorn PA. Progress in diagnosis and treatment of chronic inflammatory demyelinating polyradiculoneuropathy. Lancet Neurol. 2019;18(8):784-794.

3. Durbec P, Gennarini G, Goridis C, Rougon G. A soluble form of the F3 neuronal cell adhesion molecule promotes neurite outgrowth. J Cell Biol. 1992;117(4):877-887.

4. van Lierop ZY, Wieske L, Koel-Simmelink MJ, et al. Serum contactin-1 as a biomarker of long-term disease progression in natalizumab-treated multiple sclerosis. Mult Scler J. 2021:135245852110100.

5. Ai N, Liu H, Zhou H, et al. Cytokines and chemokines expression in serum of patients with neuromyelitis optica. Neuropsychiatr Dis Treat. 2019;15:303-310.

6. Joint Task Force of the EFNS and the PNS, Van den Bergh PYK, Hadden RDM, Illa AHI, et al. European Federation of Neurological Societies/Peripheral Nerve Society guideline on management of chronic inflammatory demyelinating polyradiculoneuropathy: report of a joint task force of the European Federation of Neurological Societies and the Peripher. Eur J Neurol. 2010;17(4):356-363.

7. Martín-Aguilar L, Pascual-Goñi E, Lleixà C, et al. Antibodies against nodo-paranodal proteins are not present in genetic neuropathies. Neurology. 2020;95(4):e427-e433.

8. Querol L, Rojas-García R, Diaz-Manera J, et al. Rituximab in treatment-resistant CIDP with antibodies against paranodal proteins. Neurol Neuroimmunol Neuroinflammation. 2015;2(5):e149. 


\section{Neurology \\ Neuroimmunology \& Neuroinflammation}

Serum Contactin-1 in CIDP: A Cross-Sectional Study

Luuk Wieske, Lorena Martín-Aguilar, Janev Fehmi, et al.

Neurol Neuroimmunol Neuroinflamm 2021;8;

DOI 10.1212/NXI.0000000000001040

This information is current as of July 20, 2021

\section{Updated Information \& Services}

References

Subspecialty Collections

Permissions \& Licensing

Reprints including high resolution figures, can be found at: http://nn.neurology.org/content/8/5/e1040.full.html

This article cites 7 articles, 1 of which you can access for free at: http://nn.neurology.org/content/8/5/e1040.full.html\#\#ref-list-1

This article, along with others on similar topics, appears in the following collection(s):

Chronic inflammatory demyelinating polyneuropathy

http://nn.neurology.org//cgi/collection/chronic_inflammatory_demyeli nating_polyneuropathy

Information about reproducing this article in parts (figures,tables) or in its entirety can be found online at:

http://nn.neurology.org/misc/about.xhtml\#permissions

Information about ordering reprints can be found online: http://nn.neurology.org/misc/addir.xhtml\#reprintsus

Neurol Neuroimmunol Neuroinflamm is an official journal of the American Academy of Neurology.

Published since April 2014, it is an open-access, online-only, continuous publication journal. Copyright

Copyright $\odot 2021$ The Author(s). Published by Wolters Kluwer Health, Inc. on behalf of the American Academy of Neurology.. All rights reserved. Online ISSN: 2332-7812.

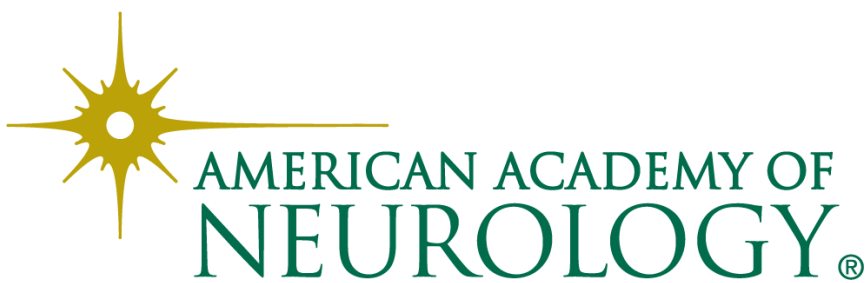

